\title{
CONF-960477-.
}

DISTRIBUTION OF THIS DOCUMENT IS UNLAMITED ${ }^{\text {IR }}$

\section{CLEAN ENOUGH FOR INDUSTRY? AN AIRBORNE GEOPHYSICAL CASE STUDY}

\author{
Jonathan E. Nyquist and Les P. Beard \\ Oak Ridge National Laboratory \\ P.O. Box 2008, Oak Ridge TN, 37831 \\ nyq@ornl.gov
}

\begin{abstract}
Data from two airborne geophysical surveys of the Department of Energy's Oak Ridge Reservation (ORR) were extremely valuable in deciding whether a 1000 -acre ( 400 hectare) parcel of the ORR should be released to the City of Oak Ridge for industrial development. Our findings, based on electromagnetic and magnetic data, were incorporated in the federally mandated Environmental Assessment Statement (EAS), and in general supported claims that this land was never used as a hazardous waste disposal site. We estimated the amount of iron required to produce each anomaly using a simple dipole model. All anomalies with equivalent sources greater than approximately $1000 \mathrm{~kg}$ of iron were checked in the field, and the source of all but one identified as either a bridge, reinforced concrete debris, or a similarly benign object. Additionally, some smaller anomalies (equivalent sources of roughly $500 \mathrm{~kg}$ ) have been checked; thus far, these also have innocuous sources. Airbome video proved invaluable in identifying logging equipment as the source of some of these anomalies. Geologic noise may account for some of the remaining anomalies. Naturally occurring accumulations of magnetic minerals in the soil on the ORR have been shown to produce anomalies which, at a sensor height of $30 \mathrm{~m}$, are comparable to the anomaly produced by about $500 \mathrm{~kg}$ of iron. By comparison, the electronic noise of the magnetic gradiometer, $0.01-0.02 \mathrm{nT} / \mathrm{m}$, is equivalent to only about $50-100 \mathrm{~kg}$ of iron at a $30 \mathrm{~m}$ sensor height. The electromagnetic data, combined with field mapping of karst structures, provided evidence of a northeast-southwest striking conduit spanning the parcel. The possible existence of a karst conduit led the EAS authors to conclude that this is a "sensitive hydrologic setting." We conclude that aerial geophysics is an extremely cost-effective, and efficient technique for screening large tracts of land for environmental characterization.
\end{abstract}

\section{INTRODUCTION}

The proposed action evaluated in this environmental assessment (EA) is the lease of approximately 1000 acres of the U.S. Department of Energy (DOE) land on the Oak Ridge (Tennessee) Reservation (ORR) to the East Tennessee Economic council (ETEC). Under the authority granted in Section 3154 of the Defense Authorization Act of 1994 (Public Law 103-160), the Secretary of Energy may lease real property at a DOE facility that is (1) to be closed or reconfigured, (2) not currently needed by DOE, and (3) under DOE control. Per the terms of the proposed lease, the sole purpose for which the lessee (ETEC) would use the parcel of land (designated Parcel ED-1) would be to further and support economic development in the region. The need for DOE action is driven by a decreased budget that will impact jobs and the economy on Oak Ridge and surrounding communities. The proposed action is wholly intended to help offset potential economic losses resulting from DOE and contractor downsizing in the near term and to diversify the economic base of the region in the long term. (Draft Environmental Assessment, DOE/EA1113, August 1995)

With this opening paragraph of the Environmental Assessment DOE clearly states that it plans to lease part of the 35,000 acre $\left(142 \mathrm{~km}^{2}\right)$ Oak Ridge Reservation for economic development. The ED-1 land parcel is one of several candidate areas ( the ED-I parcel is labeled Par. 1 in Figure 1). Before this parcel can be developed, however, the National Environmental Protection Act (NEPA) requires that the DOE prepare an environmental assessment to address the potential effects of the proposed development on the environment, and the Comprehensive Environmental Response, Compensation, and Liability Act (CERCLA) requires a review of the site for existing hazards. Although

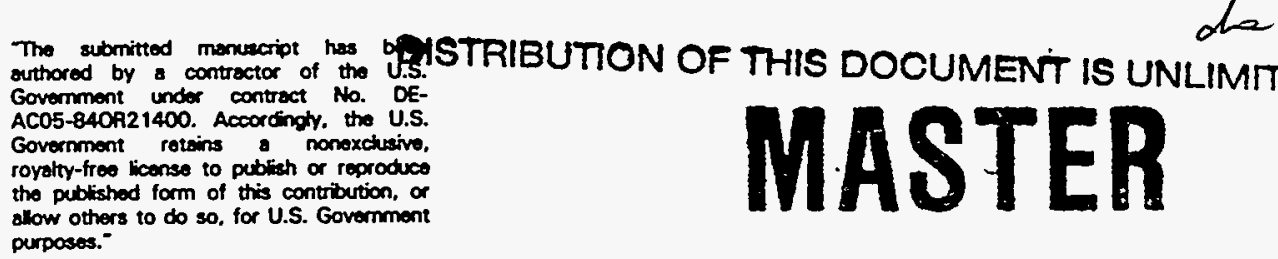


there is no record that the ED-1 land parcel was ever used for waste storage or disposal, the entire Oak Ridge Reservation is a Superfund site. Consequently, as part of the CERCLA review DOE asked the Environmental Restoration (ER) Remote Sensing Program to examine all relevant data.

In 1992-93, the ER Remote Sensing Program collected aerial geophysical data over the entire Oak Ridge Reservation, including measurements of the magnetic total field, vertical magnetic gradient, and multi-frequency electromagnetic induction (Doll et al., 1993). In this paper, we describe the results of our review of the airborne geophysical data for the ED-1 land parcel, our follow-up field investigations, and the consequences for the environmental assessment of the ED-1 land parcel. Only the geophysical findings are discussed; the results of the wetlands, biodiversity, ambient noise, and other surveys conducted as part of the environmental assessment are not discussed in the paper.

\title{
DESCRIPTION AND HISTORY OF THE ED-1 LAND PARCEL
}

A patchwork of small farms and coal mining communities blanketed the area which now comprises the ORR until 1942, when the federal government chose this area to be the site of one of the Manhattan Project production facilities. To isolate the Oak Ridge facilities, the government annexed over 35,000 acres $\left(142 \mathrm{~km}^{2}\right)$ of land. This land has remained under federal control for more than fifty years. Presently, the ORR includes three main facilities: the K-25 Gaseous Diffusion Plant, the Y-12 Plant, and the X-10 plant (commonly known as Oak Ridge National Laboratory). Also within the ORR are a number of hazardous waste burial grounds. The majority of the ORR, however, is farm land that has reverted to forest. Historical aerial photographs taken prior to 1942 show a number of small farms on the ED-1 land parcel, but the area is now largely covered with neat rows of pine trees planted as part of a tree farming study.

The local geology is complex. East Tennessee is part of the Appalachian thrust and fold belt; consequently, the regional topography exhibits a series of nearly parallel valleys and ridges. The ED-1 land parcel consists of roughly 1000 acres $\left(4 \mathrm{~km}^{2}\right)$ of land located east of the K-25 plant and west of the City of Oak Ridge in a valley bounded by Pine Ridge to the south and Black Oak Ridge to the north. East Fork Poplar Creek flows from east to west across the center of the parcel, and drains into the Clinch River near the K-25 plant. Across most of the ORR the local geology consists of Cambrian to Mississippian age shale and limestone beds, which strike parallel to the valleys, and dip to the south at average 45 degrees. The ED-1 land parcel is underlain by the predominately carbonate Chickamauga Group, and includes part of the structurally complex East Fork Syncline. Typically, the shales are highly fractured, the carbonates riddled with solution cavities, creating a complex hydrogeologic setting (Hatcher et al., 1992).

\section{DISCUSSION OF THE AERIAL DATA FOR ED-1 AND THE SURROUNDING AREA}

\begin{abstract}
Background
In 1992-3, reconnaissance airborne geophysical data was collected for the entire ORR, with an average line spacing of $50 \mathrm{~m}$. The average electromagnetic sensor flight height was $30 \mathrm{~m}$ above the ground surface; the magnetometers where on the tow cable $20 \mathrm{~m}$ higher, for an average flight height of $50 \mathrm{~m}$. Based on analysis of the reconnaissance data, we selected a number of areas for high-resolution follow-up airborne surveys; these areas were flown in the spring of 1994. Fortuitously, the ED-1 land parcel is contained within one of the high-resolution survey areas, so our discussion is based on the high-resolution data.
\end{abstract}

The high-resolution surveys were flown using a small bird developed for this survey by the contractor, Geonex Aerodat. The system features a five-frequency, horizontal coplanar loop, electromagnetic induction system operating at $7426,22278,37130,51982$, and $66834 \mathrm{~Hz}$, with a transmitter-receiver coil separation of $3.76 \mathrm{~m}$. Located in the tail of the bird were a pair of high-sensitivity cesium-vapor magnetometers separated by $1 \mathrm{~m}$ to form a vertical magnetic gradiometer. Position and altitude information were provided by a differential global positioning system receiver, and both laser and radar altimeters, located within the bird. The high-resolution survey line spacing was reduced to about $40 \mathrm{~m}$, but because the area is wooded, the altitude was again about $30 \mathrm{~m}$. Although the bird altitude was roughly the same for both the reconnaissance and high resolution surveys in wooded areas, the magnetometers were $20 \mathrm{~m}$ closer to the ground in the high resolution survey because the magnetometers were mounted in the tail of the specially designed high resolution bird, rather than on the tow cable above the bird (Beard 
et al., 1995).

\section{Vertical Magnetic Gradient}

Vertical magnetic gradient data is the key to determining whether or not there is undocumented buried waste on the ED-1 land parcel, because most waste is buried in ferrous-metal waste canisters. Figure 2 shows the vertical gradient data plotted over a range of -2.8 to $5.0 \mathrm{nT} / \mathrm{m}$. The color in this figure equivalent to the range of -0.015 to 0.015 $\mathrm{nT} / \mathrm{m}$ has been rendered transparent for two reasons: first, this makes the small localized anomalies more visible by eliminating the background of nearly the same color, second, this range approximately coincides to the electronic noise of the magnetometers, so the remaining anomalies are less likely to be the result of instrument noise. The data are dominated by the magnetic response from White Wing Scrap Yard ( a waste area south of the ED-1 land parcel), a highway overpass, and several power lines, but numerous unidentified small anomalies are present within the ED-1 land parcel.

Because the goal was not simply to locate major anomalies. but to determine whether or not the parcel is "clean," small anomalies could not be ignored. This makes it vitally important to distinguish between significant anomalies and noise. At issue were instrument noise, noise induced by flight height variations, and geologic noise. We have accumulated considerable evidence that geologic noise can be an order of magnitude greater than instrument noise at several locations on the ORR. There is evidence that this geologic noise is created by accumulations of maghemite in the soil (Doll et al., 1995, Kopp and Lee, 1985).

In the case of the ED-1 land parcel we had less than week to respond to DOE's request for information, so rather than systematically catalog all of the anomalies we focused on only the strongest anomalies within, or close to, the parcel boundary. Each small, localized anomaly was converted to an equivalent dipole source strength in kilograms of iron (Breiner, 1973). All anomalies estimated at $1000 \mathrm{~kg}$ or more were field checked, along with some smaller anomalies. The results are discussed below (refer to Figure 2).

\section{ANOMALY A: WHITE WING SCRAP YARD}

White Wing Scrap Yard is a known waste area. It was used for surface storage of scrap materials by all three of the Oak Ridge plants, and although is was not intended as a burial ground, many objects are buried there. White Wing Scrap Yard is important for the characterization of the ED-1 land parcel because a tributary of West Bear Creek flows through part of the scrap yard into the ED-1 land parcel and empties into East Fork Poplar Creek, providing a potential for off-site contamination of the ED-1 land parcel. Furthermore, piezometer wells drilled at White Wing Scrap Yard encountered large solution cavities. Water level measurements revealed a closed water table, with flow directed toward the center of White Wing Scrap Yard, rather than the nearby creek. This suggests a subterranean exit path exists, probably draining in the direction of the ED-1 land parcel.

\section{ANOMALY B: HIGHWAY OVERPASS}

The largest magnetic anomaly in the survey area corresponds to a highway overpass at the junction of state highways 95 and 58. Overlaying the magnetic data on a site map or aerial photograph of the site makes it easy to identify the effects of large structures and power lines (shown in green on Figure 2).

\section{ANOMALY C: SMALL BRIDGES}

Four of the anomalies within the ED-1 land parcel were created by bridges. Three are along a gravel, two-lane perimeter road, and one was an abandoned bridge crossing East Fork Poplar Creek in the easterm portion of the land parcel (Figure 3a).

\section{ANOMALY D: LOGGING TRUCKS}

In our initial follow-up visit to the field, we failed to find the sources a number of magnetic anomalies along the roads, but not near any bridges or power lines. We reviewed the airborne video tapes collected when the survey was be flown and discovered that these anomalies corresponded to logging trucks (Figure 3b). Although the forests on the ORR are not harvested for timber, many of the pine forests planted in the ED-1 land parcel died as the result of a pine beetle infestation, and were being removed at the time of the airborne geophysical survey. This example illustrates the importance of collecting high-quality video data during airborne geophysical surveys of environmental sites as "transient anomalies" could otherwise be mistaken for buried objects. 


\section{ANOMALY E: LAMBERT'S QUARRY}

Lambert's quarry is located just outside the northeast corner of the ED-1 land parcel (Figure 2). It is not clear whether the magnetic anomalies seen in this area stem only from metal objects around the quarry, or from within the quarry itself. In our field investigations we found several possible sources around the quarry: a pile of concrete rubble containing steel reinforcing rods (rebar), a concrete pier that may have been part of a conveyor belt leading to the quarry (Figure 3c), some corroded steel cylinders probably used to hold compressed gas (Figure 3d), and a single 55-gallon drum half buried in a mound of dirt (see Figure 3e). Old truck tires and other debris were visible beneath the quarry waters near the shore, evidence that waste (not necessarily hazardous) was dumped in the quarry.

\section{ANOMALY F: UNIDENTIFIED}

We did not have time to follow-up on all of the magnetic anomalies within the ED-1 land parcel, and their sources remain unidentified. In a few cases we were unable to locate the source. At those sites a ground based magnetic survey would be required to confirm that the aerial magnetic anomaly was not the result of geologic or system noise, but this was outside the limited scope of our investigation. Note that this land is densely overgrown with trees, shrubs, and brambles (see Figures 3a-e). Even guided by the aerial magnetic data, the metallic debris that we discovered near Lambert's quarry was difficult to find.

\section{Apparent Resistivity}

Figure 4 shows the apparent resistivity determined by a inversion of the $7 \mathrm{KHz}$ electromagnetic data assuming a homogeneous halfspace. The response is a combination of the local geology and cultural features. The shaley carbonate formations are relatively conductive; the purer carbonate formations are relatively resistive. Near the northnorthwest boundary of the ED-1 land parcel is a large conductive anomaly within the Mascot dolomite and the Pond Spring limestone. This anomaly coincides with a large sinkhole that we believe has partially filled with clay. Note the east-west conductive trend connecting this sinkhole to Lambert's quarry. This trend coupled with the presence of other smaller sinkholes in the area supports the hypothesis of a groundwater conduit running along strike almost the entire length of the northern boundary of the ED-1 land parcel.

The resistivity data appears to be most sensitive to the soil and bedrock geology (note the geologic contacts overlain in gray on Figure 4). The highway overpass and White Wing Scrap Yard, noted in our discussion of the magnetic data, are also visible in the resistivity data. However, none of the smaller magnetic anomalies have corresponding conductive anomalies.

\section{CONCLUSIONS}

Based on the aerial magnetic data, we conclude that there are no major burial grounds on the ED-1 land parcel. White Wing Scrap Yard is probably the smallest of the known waste storage areas on the ORR, yet it produces a much larger magnetic anomaly than any within the ED-1 land parcel. The metallic debris surrounding Lambert's quarry deserves further investigation. Abandoned quarries are notorious for attracting illegal dumping, and Lambert's quarry is both accessible and remote. The single empty, corroded, 55-gallon drum that we discovered near the quarry probably does not represent a health hazard, but is probably left over from quarry operations. A ground-based magnetic survey would be reasonable to determine whether any buried drums are present. As a consequence of the short time-table imposed by DOE, we did not have time to investigate the remaining small magnetic anomalies, however, all but one of the anomalies equivalent to $1000 \mathrm{~kg}$ or more of iron have been identified.

The resistivities calculated from the electromagnetic induction data were more sensitive to the local soil and geology than to metallic objects. These data support what other investigators reported based on earlier field studies: the carbonate formations within the ED-1 land parcel are highly karstified, making this a sensitive hydrogeologic area. If a karst conduit exists, contaminants introduced at this site could migrate to the Clinch River (a public waterway) much more rapidly than would be predicted by non-karst groundwater flow models.

Apparently, the greatest contamination concern for the ED-1 land parcel arises not from materials disposed within the parcel, but from contaminants migrating into the parcel from other sources. That East Fork Poplar Creek carries mercury contamination from the Y-12 plant into the ED-1 land parcel was known before the lease was proposed. Consequently, the developers plan to leave the East Fork Poplar Creek floodplains untouched. West Bear Creek. 
a tributary of East Fork Poplar Creek, may carry contamination from White Wing Scrap Yard, but because there are no groundwater monitoring or stream sediment data available, this remains conjecture. Finally, we note that Lambert's quarry, which is located just outside the ED-1 boundary (Figure 2), may have been used for dumping, and deserves further investigation, as the quarry is spring fed, and may be connected to a karst conduit system running east-west across the ED-1 land parcel.

This case study shows what we believe to be the principal utility of airborne geophysical data at large hazardous waste sites: the ability to screen large areas of land for undocumented waste disposal sites. Surveying this densely vegetated 1000 acres $\left(4 \mathrm{~km}^{2}\right)$ site on foot would have been slow and expensive. Although no geophysical technique can be used to certify that an area is absolutely free of contamination, airborne geophysics shows promise as a tool to screen large areas for buried waste, and thus provide relatively inexpensive protection against major liability in the future.

\section{ACKNOWLEDGEMENTS}

This work was performed at Oak Ridge National Laboratory operated by Lockheed Martin Energy Systems, Inc., for the U. S. Department of Energy under contract DE-AC05-84OR21400. Financial support was sponsored by the Oak Ridge Environmental Remote Sensing Program.

\section{REFERENCES}

Beard, L.P., J.E. Nyquist, and W.E. Doll (1995), High Resolution Geophysics at Hazardous Waste Disposal Sites, Proceeding of the Symposium on the Application of Geophysics to Engineering and Environmental Problems, Environmental and Engineering Geophysical Society, p647-662.

Breiner, S (1973), Applications manual for portable magnetometers, GeoMetrics, 58 pp.

Doll, W.E., J.E. Nyquist, J.S Holladay, V.F. Labson, and L. Pellerin (1993), Preliminary results of a helicopter electromagnetic and magnetic survey of the Oak Ridge Reservation, Tennessee for environmental and geologic site characterization. Proceeding of the Symposium on the Application of Geophysics to Engineering and Environmental Problems, Environmental and Engineering Geophysical Society, p. 281-295.

Doll, W.E., J.M. Helm, and L.P. Beard (1995), Airborne Detection of Magnetic Anomalies Associated with Soils on the Oak Ridge Reservation, Tennessee. Proceeding of the Symposium on the Application of Geophysics to Engineering and Environmental Problems, Environmental and Engineering Geophysical Society, p. 619626.

Environmental Assessment, Draft Document, Lease of Parcel ED-1 of the Oak Ridge Reservation by the East Tennessee Economic Council, DOE/EA-1113, August 1995, 122 pp.

Hatcher, R.D., Jr., Lemiszki, P.J., Dreier, R.B, Ketelle, R.H., Lee, R.R., Leitzke, D.A., McMaster. W.M., Foreman, J.L., and Lee, S.Y. (1992), Status report on the geology of the Oak Ridge Reservation, ORNL/TM-12074, $244 \mathrm{pp}$.

Kopp, O.C. and Lee, S.Y., (1985), An unusual occurrence of maghemite in soils developed on dolostones of the Knox Group, Oak Ridge, TN, Proceedings of the Internaltional Clay Conference, Denver, p 205-211.

Review of Parcel ED-i, Under Section 120 (h) of the Comprehensive Environmental Response, Compensation, and Liability Act and Section XIIII of the Federal Facility Agreement, August 1995, 13pp. 
ORR Parcels Identified for City of Oak Ridge Self Sufficiency Agreement

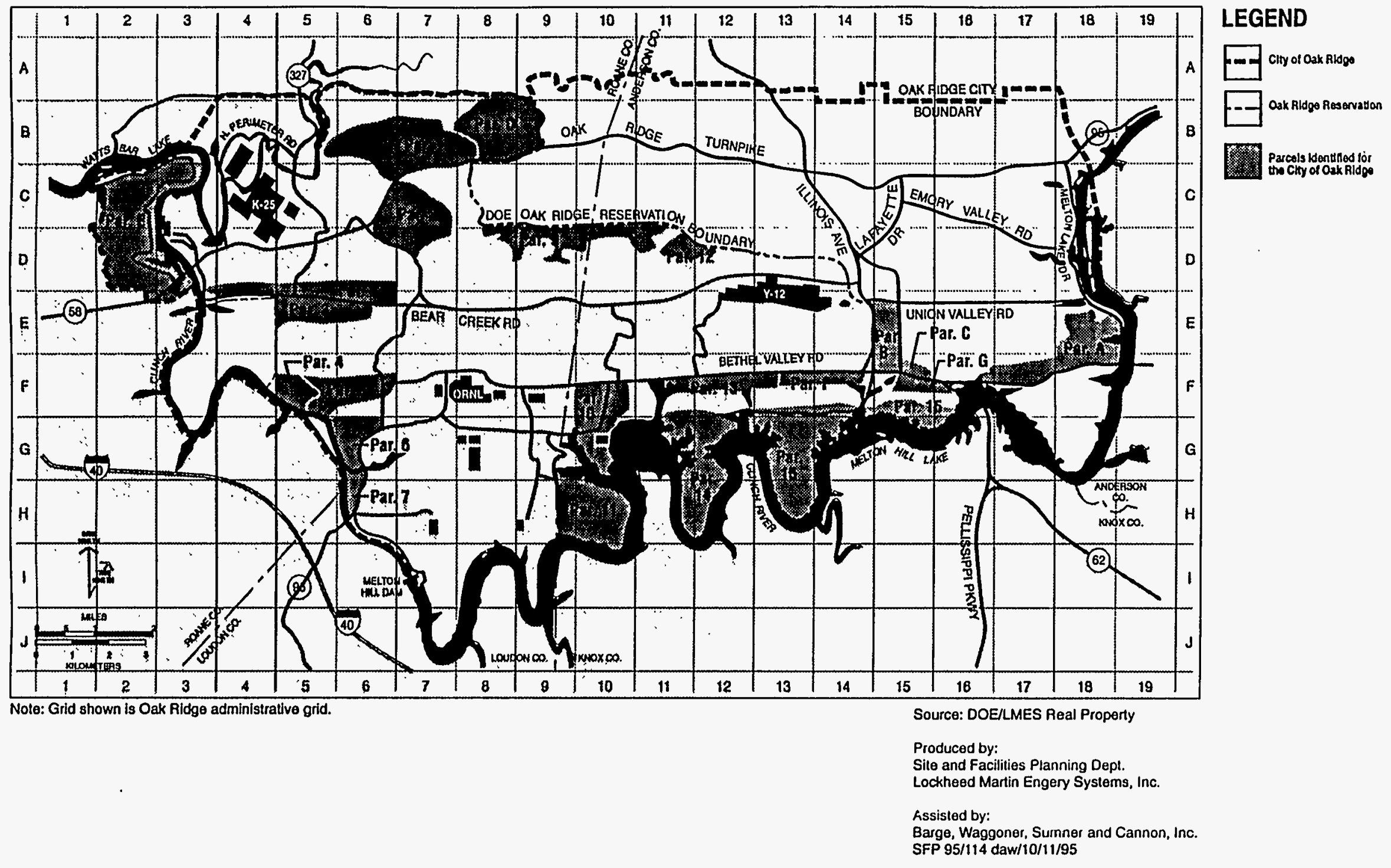



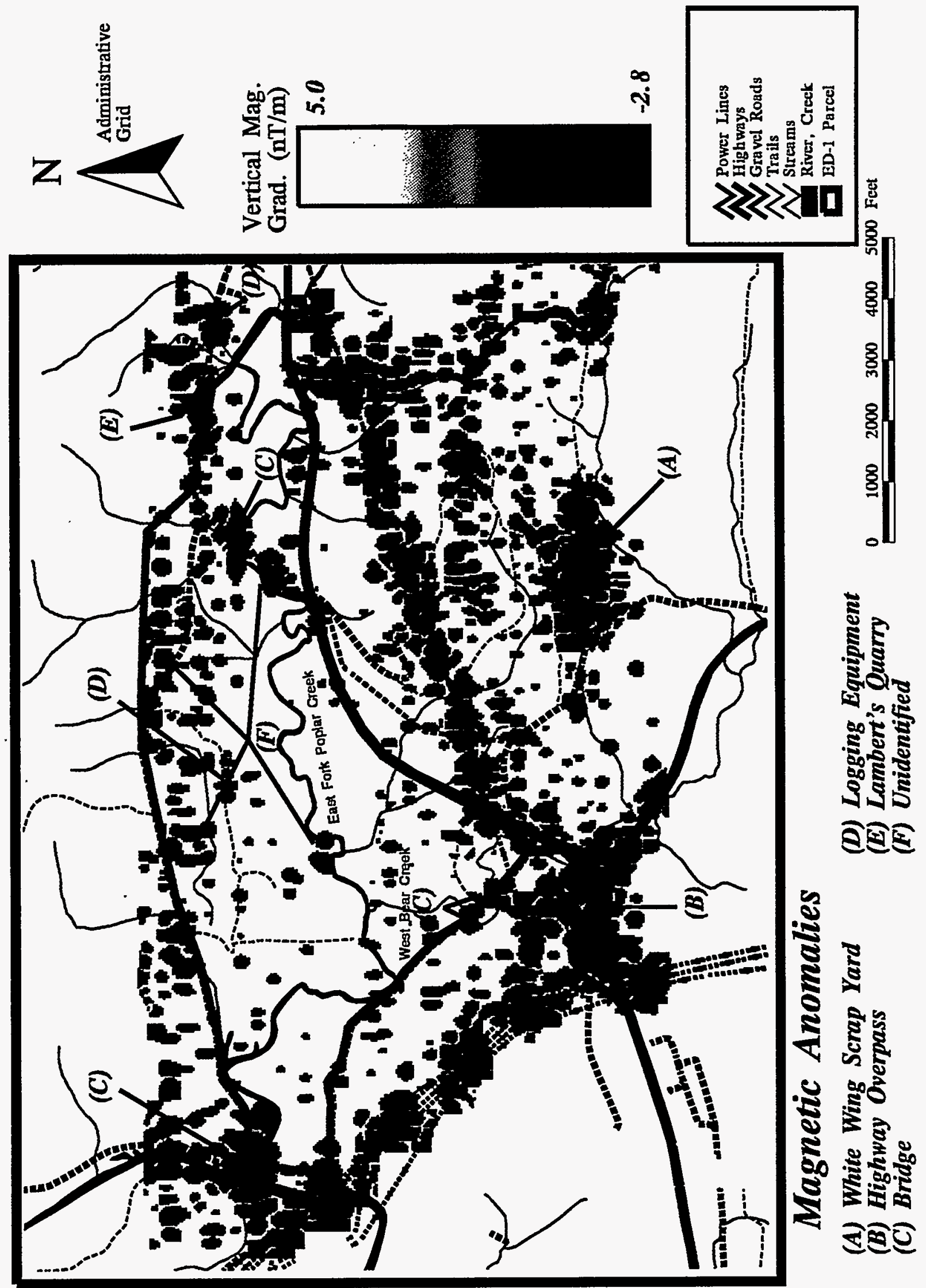


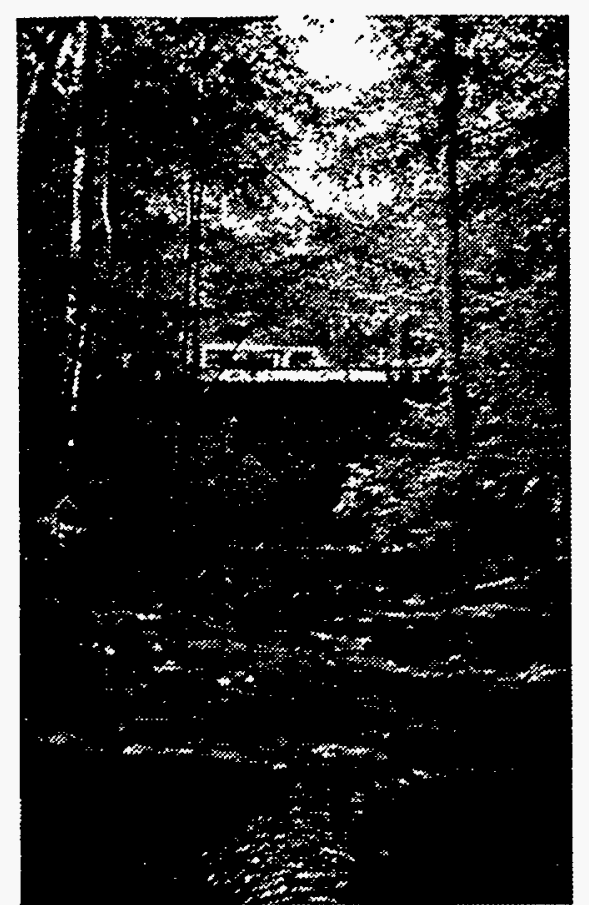

Figure 3a. Bridge over West Bear Creek

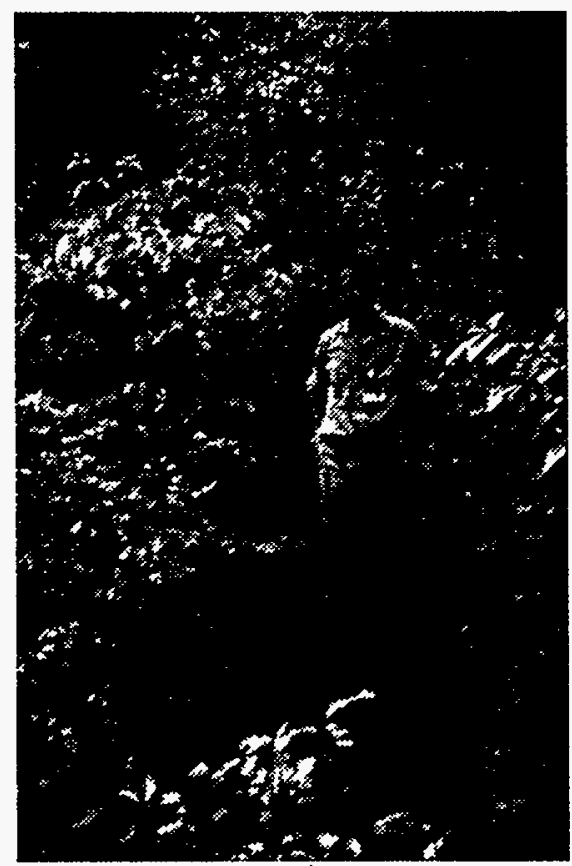

Figure 3e. Corroded 55-gal drum found near Lainbert's Quarry.

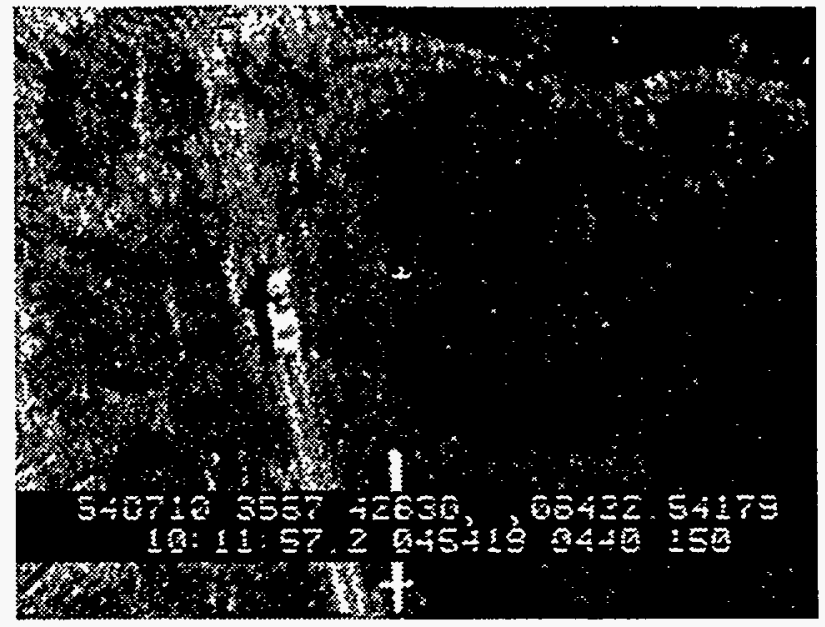

Figure $3 \mathrm{~b}$. Logging truck captured on video taken from the helicopter performing the aerial geophysical survey.

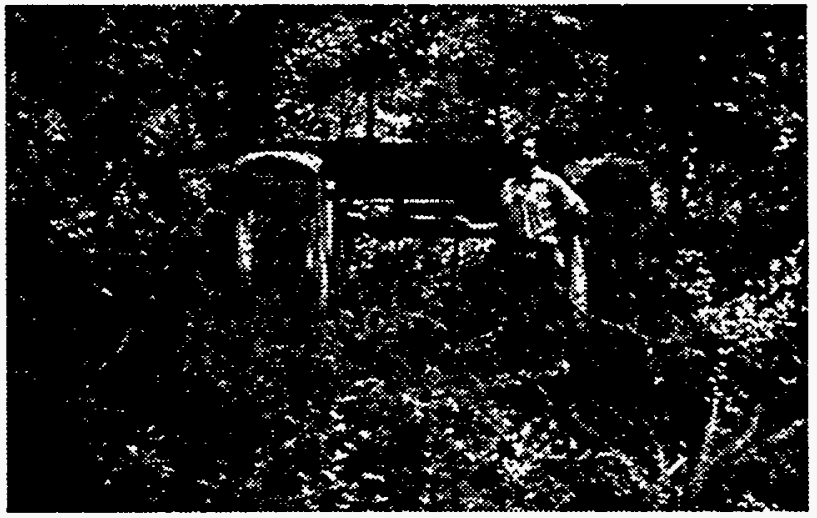

Figure $3 \mathrm{c}$. Reinforced concrete structure found near Lambert's Quarry.

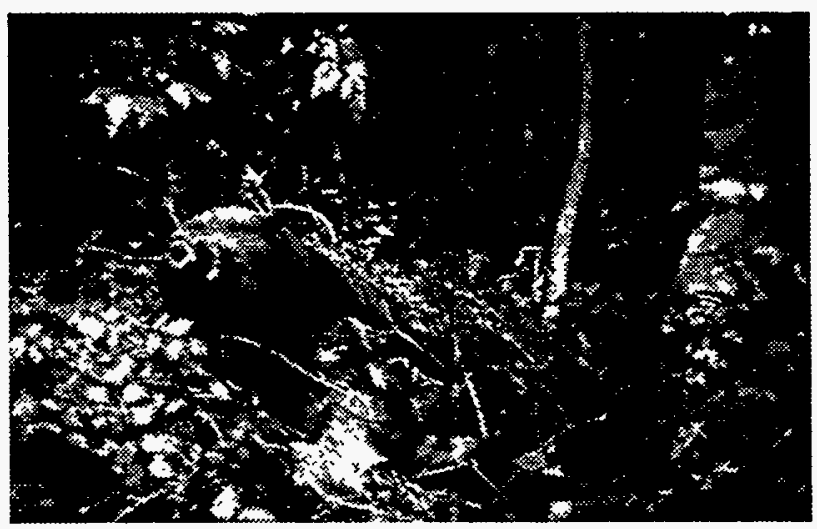

Figure $3 \mathrm{~d}$. Half-buried compressed-gas cylinder found near Lambert's Quarry. 


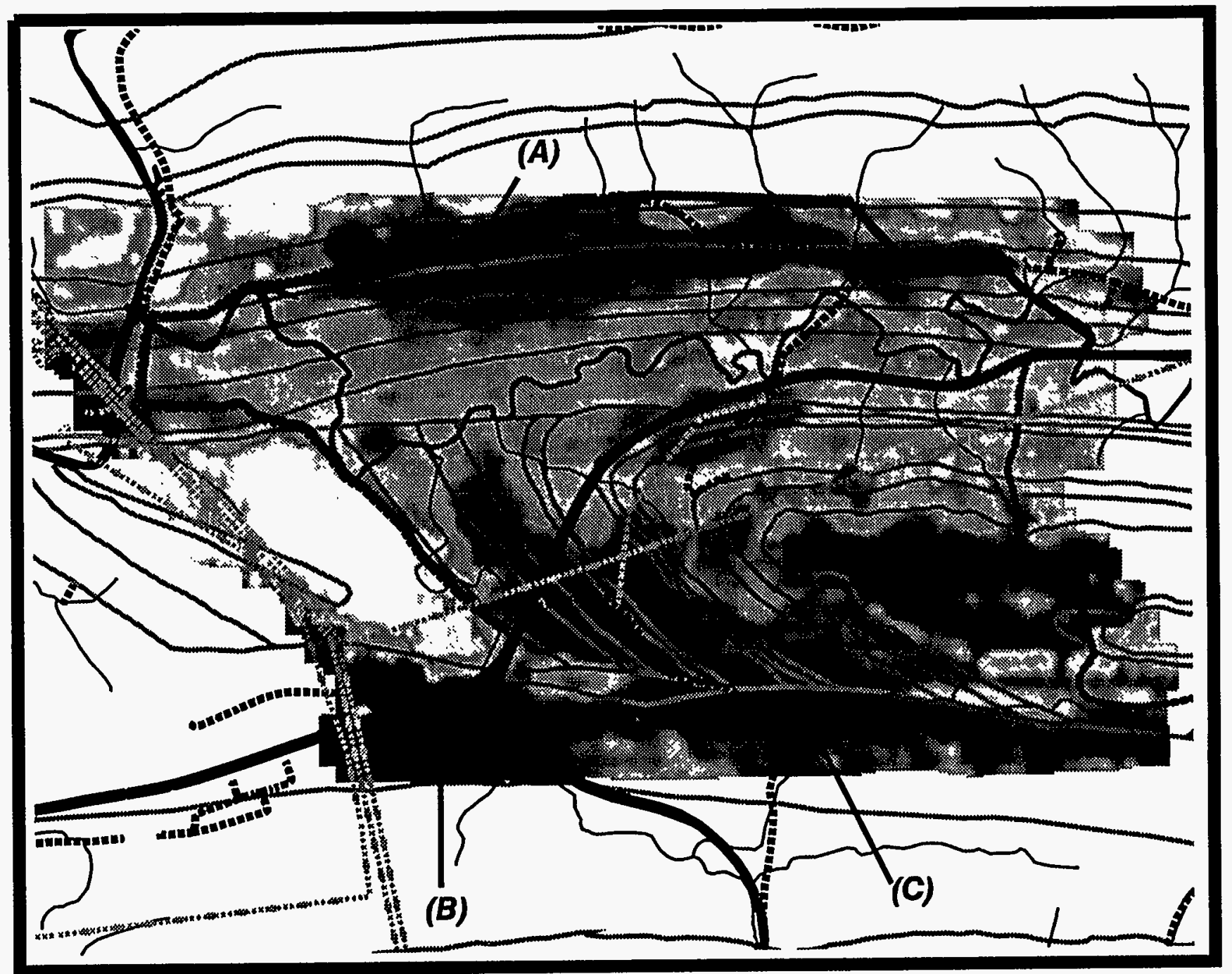

Resistivity Anomalies

(A) Major Sinkhole

(B) Highway Overpass

(C) White Wing Scrap Yard

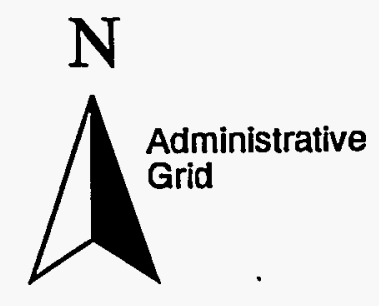

Electrical

Resistivity

(Log10 mS/m)

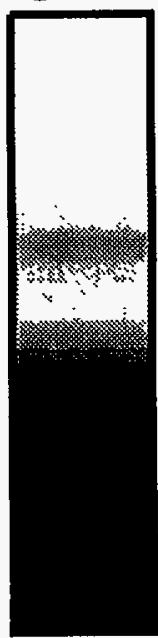

3.3

1.7

A Power Lines

Highways

Wravel Roads

Siver,

ED-1 Parcel

Geology.shp 